\title{
Impeachment, Political Crisis and Democracy in Brazil
}

\author{
Impeachment, crisis politica y democracia en Brasil
}

\section{FELIPE NUNES}

Universidade Federal de Minas Gerais, Brasil

\section{CARLOS RANULFO MELO}

Universidade Federal de Minas Gerais, Brasil

\begin{abstract}
The year 2016 was marked by the deepening of the crisis that interrupted two decades of unusual political stability in Brazil. Although it has been the most significant event, Dilma Rousseff's impeachment did little to "stop the bleeding," as was shown by the subsequent arrest of the former president of the Chamber of Deputies, Eduardo Cunha (PMDB), and the unfolding of Operation Car Wash (Lava Jato). Besides the economic problems, the Brazilian political system also faced a serious crisis of legitimacy: the main parties were put in check, and a period of uncertainty regarding electoral and partisan competition opened up. In this article, we will review the sequence of the events, exploring some of the factors that explain it, and, aware of the fact that we are in the middle of process with an undefined outcome, we would like to take advantage of the opportunity to resume the debate on the performance of Brazilian democracy as well its perspectives.
\end{abstract}

Key words: democracy, presidentialism, political crisis, presidential interruption, Brazil

\section{RESUMEN}

El año 2016 estuvo marcado por la profundización de una crisis que interrumpió dos décadas de inusual estabilidad política en Brasil. A pesar de ser el acontecimiento político más significativo del año, el enjuiciamiento de Dilma Rousseff hizo poco para detener el "sangrado," como lo demostró la posterior detención del ex presidente de la Cámara de Diputados, Eduardo Cunha (PMDB), y el despliegue de la Operación Coche Lavado (LavaJato). Sumado a los problemas económicos latentes en el país, el sistema político brasileño se enfrenta a una grave crisis de legitimidad: los principales partidos están cuestionados lo que facilita un periodo de incertidumbre en términos de competencia electoral y partidista. En este artículo, revisamos la secuencia de los eventos ocurridos en 2016, explorando algunos de los factores que los explican, conscientes que estamos aún inmersos en un proceso con un resultado indefinido. Aprovechamos esta oportunidad para reanudar el debate sobre el desempeño de la democracia brasileña y sus perspectivas a futuro.

Palabras clave: democracia, presidencialismo, crisis, presidencia interrumpida, Brasil 


\section{INTRODUCTION}

For two decades, Brazil contradicted pessimistic prognoses about the development of its democracy (Mainwaring 1999; Ames 2001), but in 2013 it entered into a period of strong political instability. That year, for the first time since redemocratization, crowds occupied the streets without the presence of political parties and/or civil society organizations. Initially directed at a municipal issue - the price of bus fare - the agenda of the protests quickly expanded to oppose the entire political system, and their impact was strongly felt by the government. In March 2014, the first arrests made as part of Operation Car Wash ${ }^{1}$ began to expose a monumental scheme to divert Petrobras's resources. Protests against hosting the World Cup arose shortly thereafter something previously unthinkable in the "soccer nation" - and the fiercest and most polarized presidential campaign since 1989 followed. Once the polls had closed, the street protests in favor of the President's impeachment began. At the beginning of 2015, Eduardo Cunha (PMDB) was elected president of the Chamber of Deputies, defeating the candidate from the PT and the government. In March 2016, former president Lula was seized by the Federal Police and forced to testify at a military base at Congonhas airport. The status of the economy continued to get worse. Finally, after months of conflict between the executive and legislative branches, the Chamber of Deputies authorized the initiation of proceedings for the impeachment of Dilma Rousseff in April 2016. On 31 August, after the Senate made its decision, Vice President Michel Temer formally assumed the presidency.

There was still no light at the end of the tunnel. As the Operation Car Wash investigations deepened, the political sphere was near panic. In October 2016, after losing his parliamentary immunity, Eduardo Cunha was arrested by order of judge Sérgio Moro, who was responsible for Operation Car Wash. In November of the same year, depositions of executives from Odebrecht, involving dozens of politicians from a wide variety of parties, reached the core of the new government. To address this process and how it unfolded, this article is organized in four sections in addition to this introduction (I). In the next section (II), we will focus on Dilma's impeachment, with the aim of pinpointing its determining factors and highlighting similarities and differences with respect to other interruptions of presidential tenures that occurred in Latin America. In section III, we turn our attention to the Michel Temer government, its relationship with the legislature, and the composition of the Ministry. We show that the new agenda aims to confront economic woes with orthodox measures;

\footnotetext{
Operation Car Wash started with the investigation of money traders who used a network of gas stations in the city of Curitiba - capital of the state of Paraná - to move resources obtained illegally. The Federal Public Prosecutor's Office subsequently called the case a scheme to divert Petrobras's resources, involving company employees, financial operators, contractors, and politicians from the PT, PMDB, and PP. Dozens of provisional or definitive arrests have already been made. Created in 1953 during Getúlio Vargas's government, Petrobras (Petróleo Brasileiro S.A.) is a publicly traded company. The majority shareholder is the Government of Brazil. It is a mixed state-owned enterprise, operating in the oil, natural gas and energy industries.
} 
after 13 years of PT's mandate this agenda is a right turn, but this change is unlikely to be sufficient to overcome the crisis of legitimacy that the country faces. Section IV analyses the municipal elections. The intention here is not only to narrate one of the rare "normal" occurrences of the year, but to highlight its relationship with the ongoing crisis and its possible effects in the next elections in 2018. Finally, as a conclusion and in light of the points discussed above, the last section $(\mathrm{V})$ resumes the discussion of the current Brazilian institutional arrangement, its virtues, and its recent problems.

\section{ROUSSEFF'S IMPEACHMENT}

Looking over the long series of presidencies that have been interrupted since the 1980s in Latin America, the literature highlights the process of interaction between at least four variables: economic crises, corruption scandals involving the president and his or her party, broad and systematic protests, and the loss of a legislative majority by the executive (Negretto 2006; Hochstetler 2007; Marsteintredet 2008; Pérez-Liñan 2008). Analyzed as a whole, the succession of events calls into question the assertion that in presidential democracies, there is no political way to end an executive term early, pointing to resignations, legislative coups, or the occurrence of political judgments as outlets for the crises.

To understand Rousseff's case, it's necessary to distinguish between the causal elements without which the context of the crisis would not have been configured, and the mechanisms that were effectively capable of leading to the interruption of the tenure in question. Part of the explanation is regarded to the economical crisis and the mismatch between what Rousseff promised in the campaign and what happened to the country's economy soon after the inauguration. The other part of the explanation is attributed to the movements in Congress and the mass protests.

In economic terms, the situation in 2016 had worsened relative to the previous year. After a 3.8\% contraction in 2015 (Ribeiro, Visoná and Cassota 2016), projections of the Ministry of the Treasury pointed to a $3.5 \%$ reduction in the Gross Domestic Product (GDP) at the end of 2016 (Marchesini 2016). Also, for the second year in a row, the public sector closed 2016 with a significant deficit: $\mathrm{R} \$ 155.791$ billion, equivalent to $2.47 \%$ of the GDP (Campos and Bonfanti 2016). ${ }^{2}$ The recession caused unemployment to explode, toppling the last bastion of the PT-era economic design. After steadily growing since the beginning of 2015, the number of people unemployed surpassed 12 million in 2016, which, according to data from the IBGE [Brazilian Institute of Geography and Statistics], corresponded to $11.9 \%$ of the working age population (Araújo and Lara 2016). The only good news had to do with inflation; after reaching $10.67 \%$ in 2015, it 
began to fall and closed the year at 6.29\% (Cury, Boeckel and Cavallini 2017). But the news did not bring the government any relief, perhaps because the impact of the fall was not felt quickly, or perhaps because a broad majority of the population had already developed the conviction that the crisis was the responsibility of the PT government and that Dilma hid the situation during the 2014 campaign.

The decline of the economy came to be associated with the revelations of Operation Car Wash. Initial reports from 2014 indicated that large contractors organized in a cartel had paid bribes to senior executives at Petrobras and to political actors for years. The bribes varied from $1 \%$ to $3 \%$ of the value of inflated contracts for major projects. The scheme of diverting funds functioned via the Supply, Services, and International Departments of the oil company, the heads of which would have been appointed, respectively, by the PP, PT and PMDB. The first plea bargains, ${ }^{3}$ the magnitude of the numbers, and the arrests of the executives of the largest companies in the country, combined with the importance and symbolism of Petrobras, had a strong impact on public opinion, deepening the strain on the government and the PT. For the second time in a few years, the party was at the center of a major corruption scandal. Although she was not mentioned in any plea bargains, the fact that Dilma Rousseff had presided over the company's Administrative Board from 2003 to 2010 was explored in detail. Likewise, there was no way to ignore the fact that PT members trusted by Lula held the presidency of the national oil company from 2003 to 2012. Finally, the arrests of former minister José Dirceu, ex-Senator Delcidio do Amaral, and of another two former treasurers of the party completed the scenario ${ }^{4}$

The feeling that Rousseff Dilma was responsible for the economic crisis and the first revelations of the Lava Jato were enough to make the political capital of the government rapidly disappear. In November 2014, 46\% of the population still considered the PT government to be excellent or good (Amaral and Ribeiro 2015), but this curve was inverted just a few months later, when 65\% considered Rousseff's management to be bad or terrible (Datafolha 2016), a baseline that would be maintained with only slight oscillations until the eve of the impeachment, and that would be decisive in attaining this result.

In the wake of the economic crisis and of Operation Car Wash, the two mechanisms responsible for deposing Rousseff began. First, protesters took to the streets. According to Hochstetler (2007) and Pérez-Liñán (2007, 2008), street demonstrations may be considered the most important variable in the interruption of presidential tenures in Latin America. In the Brazilian case,

\footnotetext{
When making a plea bargain, the accused must identify accomplices and people who benefited from the crimes investigated and return the money lost. The plea is only accepted if it carries evidence and adds something to the investigation. In exchange, the informer has a reduced sentence and even benefits like house arrest. The first to provide such information was Paulo Roberto Costa, Supply Director.

4 Accused of running a scheme that directed illegal resources to government coalition partners, José Dirceu had been arrested for the first time in 2015 along with another PT treasurer, Delubio Soares, in the so-called "mensalão" scandal. The other two treasurers arrested were João Vacari and Paulo Ferreira.
} 
two additional observations can be made. First, the socioeconomic profile of the protesters was always far from representative: surveys done by DataFolha showed that most protesters were older, highly educated, and with higher income (Bächtold 2016). ${ }^{5}$ Second, after a spectacular start in 2015, with nearly a million people throughout the country participating, the protests lost force. By December, they were similar in size to counter-protests in favor of the government. The number of pro-impeachment participants fell from 200 to 40 thousand in São Paulo, which was the most mobilized state (UOL 2005, 12 December).

At this point, the leading role in the process had already been assumed by the legislature, led by Eduardo Cunha's initiatives. Thus, the second and more important mechanism mentioned above was put into action.

In Brazilian coalition presidentialism, the relationship between the executive and legislative powers has always been a key factor for the success of governments. This was especially true of Dilma Rousseff's second term. After 2014, the country faced the most fragmented Congress in its history. In the Chamber of Deputies, the effective number of parties reached 13.3, and in the Senate the effective number of parties reached 8.4. ${ }^{6}$ To deal with this problem, Dilma formed a 10-party coalition that in theory would give her 328 votes $(64 \%$ of the house). Such a coalition, however, never worked.

Problems started with the establishment of the first cabinet. Unsatisfied, the president of the Senate, Renan Calheiros (PMDB), said that his party felt "humiliated" (Brito 2015). In fact, the composition of the ministry was intended to weaken the PMDB and, at the same time, to strengthen the PSD within the governing coalition. The strategy soon turned out to be a gross mistake. The PMDB was the coalition's second-largest party and during Rousseff's first term had secured strong support for the government, especially in the Senate. After the announcement of the new ministry the leadership of Calheiros caused that the support to the government between the senators diminished substantially.

The election of Eduardo Cunha to the Presidency of the Chamber, in February 2015, made Rousseff's relationship with the legislature even more difficult. Since being elected leader of the PMDB in 2013, Cunha had been working to undermine the PT's strength and to implode the alliance between the two parties. In the 2014 general elections, Cunha used his abundant resources to expand his power and establish the foundations for his own power base in the Chamber,

In this sense, the protests of 2015 were distinct from those held in 2013, which had been initiated by young people with a different socioeconomic profile.

In Brazil, each state elects three senators to serve staggered eight-year terms. The Senate is renewed each four years. First, a third of the seats are placed in dispute, one by state (plurality system). Four years after is the other two-thirds turn - in each state being elected the two top candidates regardless of party (block vote). The degree of party fragmentation in the Senate is not entirely explained by the electoral system. More important is the absence of a nationalized party system, which means that party strength varies depending on the State in question. 
more powerful that of his party. Congressional opposition, movements against the government in civil society, and sectors of the media quickly saw him as the actor capable of interrupting the long PT cycle.

In this context, Cunha's controversial past was set aside in exchange for activism ahead of the House and against the government. ${ }^{7}$ Under his command, PMDB support for government fell from $80 \%$ to $60 \%$ (Limongi 2015), and, throughout 2015 , the Chamber blocked the approval of government measures intended to reverse the economic situation - despite Rousseff's appointment of then Vice President Michel Temer as her political articulator in Congress. Rather than discussing measures to correct the fiscal deficit, the deputies approved a series of measures that increased public expenditures, forcing Rousseff to use the presidential vetos.

With the prerogative of opening the process of impeachment by monocratic decision $^{8}$, Eduardo Cunha had begun to use his strategic position against the government in July 2015, accusing it of being behind the charges against him in Operation Car Wash. The blackmail became more explicit when the Chamber's Ethics Committee came to discuss the forfeiture of his mandate based on the fact that he had lied about bank accounts opened in Switzerland. Finally, on 2 December 2015, Eduardo Cunha granted one of the requests sent to Congress, and the impeachment began. The request was granted on the same day that deputies from PT announced that they would vote against Cunha in the committee.

As stated by Limongi (2015: 105), "it was up to Cunha to revive the movement." Once the process had begun in the Chamber of Deputies, the largest street protests against the government were recorded in March 2016, with 500 thousand people in São Paulo, according to DATAFOLHA. A few days later, it would be the turn of the pro-government protesters, although these counter-protests were only one-fifth as large (UOL 2016). The remainder of the impeachment process unfolded in Congress, without significant protests.

At the beginning of 2016 it was clear that the relationship between Rousseff and Congress had soured. The last attempt to save her mandate came in March, with the appointment of Lula as one of her ministers - relying on the former president's political savvy and good relationships with important congressional leaders, Rousseff sought to rebuild her legislative base, albeit in a partial way.

In the early 1990s, Eduardo Cunha was dismissed as the chair of state telephone company of Rio de Janeiro (TELERJ) on account of an overbilling scheme of involving company contracts. He also was implicated in the investigation on the scheme of Paulo César Farias (Fernando Collor's former treasurer). In 2001, he had to abandon the presidency of the Rio State Housing Company due to corruption charges. In 2005, during the Mixed Parliamentary Commission investigating the Postal Service, he was associated with money trader Lucio Funaro, who paid the rent for his luxurious apartment in Brasilia. Despite this information being in the public knowledge, the Brazilian press did not cover these stories at the time of Cunha's ascension to the presidency of the Chamber of Deputies. See Boulos (2015).

8 The Brazilian Constitution grants the President of the Chamber the prerogative of accepting or not the requests for impeachment sent to the National Congress. 
However, the appointment was blocked by decision of Gilmar Mendes, Minister of the Supreme Federal Court, on the grounds that it constituted an attempt to protect the former president from Operation Car Wash investigations. Dilma no longer had the conditions to govern. In April, in the vote in which the Chamber of Deputies decided to open impeachment proceedings, the government coalition had dissolved and only 137 votes $-26.5 \%$ of the House - remained loyal to Rousseff. Table 1 shows how the deputies voted: among the 367 votes favorable to impeachment, 198 (54\%) came from parties that had formerly been part of the governing coalition. Even more than the street protests, the loss of this legislative majority was the decisive factor in the interruption of the presidential mandate. On 31 August, the Federal Senate approved the final removal of Dilma Rousseff by 61 votes to $20 .{ }^{9}$

Table 1. The impeachment vote in the Chamber of Deputies (April 2016)

\begin{tabular}{cccccc}
\hline \multirow{2}{*}{$\begin{array}{c}\text { Status right after the elec- } \\
\text { tion of 2014 }\end{array}$} & Party & \multicolumn{4}{c}{ Position on the impeachment } \\
\cline { 3 - 6 } & PT & 0 & 60 & & \\
& PC do B & 0 & 10 & & \\
& PDT & 6 & 12 & 1 & \\
Belonged to the govern- & PR & 26 & 10 & 3 & 1 \\
ing coalition & PMDB & 59 & 7 & & 1 \\
& PSD & 29 & 8 & & \\
& PP & 38 & 4 & 3 & \\
& PROS & 4 & 2 & & \\
\hline \multirow{5}{*}{ Declared their opposition } & PTB & 14 & 6 & & \\
& PRB & 22 & 0 & & \\
\hline & PSB & 29 & 3 & & \\
\hline Other 13 parties & PSDB & 52 & 0 & & \\
\hline Total & PPS & 28 & 0 & & \\
\hline
\end{tabular}

Source: http://www2.camara.leg.br/

Before, during, and after its consummation, the impeachment generated intense debate between those who denounced it as a "coup" and those who defended

9 The Brazilian constitution determines that it is the responsibility of the Chamber of Deputies to open the proceedings, and that it is the Senate's responsibility, under the presidency of the Head of the Supreme Federal Court, to conduct the trial and to issue a final ruling. 
the legality of the process. Certainly, there was no coup: the legal procedure was followed under the attentive eyes of the Supreme Federal Court. But this did not resolve the debate, at least on two important points.

First, the PSDB violated a basic norm of democracy in refusing to accept defeat in the 2014 presidential election, and instead sought any possible means to interrupt the PT's fourth consecutive term (Melo 2015; Limongi, 2015). Right after the election, Aécio Neves stated that he did not trust in the impartiality of the vote-counting process and asked for a recount of second-round votes, leaving the first round aside after his own candidature experienced a meteoric rise in the last days of the campaign. A few days later, Aécio declared to the press that he had been defeated by a "criminal organization." Also in 2014, the party requested that the Supreme Court investigate the alleged use of resources originating from corruption, which, they argued, made Rousseff's election illegitimate (Matais, Rosa and Bulla 2014). In 2015, the party proposed the idea of impeachment. As justification, it considered events from the period in which Rousseff presided over Petrobras' Administrative Board, and, later, the possibility that the Federal Accounts Court would condemn the government accounts for 2014. In both cases, the problem was the constitutional determination that the "crime of responsibility" - the only motive for which a president can be removed in Brazil - has to be based on acts committed during the term in progress. ${ }^{10}$

Despite the absence of a legal basis, the impeachment question lingered as a latent threat until Rousseff's opponents found possible grounds; the request, granted by Cunha, accused the president of having made six decrees to open additional credit in 2015 without Congress' authorization and using public banks to finance government programs - an accounting scheme that earned the nickname pedaladas fiscais.

This brings us to the second controversial point of the narrative. Cunha himself had rejected an earlier request to investigate the pedaladas on the grounds that similar activities had been practiced by previous governments without recrimination (Venceslau and Lopes 2015). As Elio Gaspari observed in a column in Folha de São Paulo on 29 June, "this criteria would implicate all governors, from Michel Temer to Tomé de Souza" (Gaspari 2016). ${ }^{11}$ Interviewed by the same newspaper, Joaquim Barbosa - the former Supreme Federal Court Minister, known for the rigor with which he led the trial of the mensalão and punished the PT's leaders - was emphatic, saying: "that was staged. All of the steps had already been planned since 2015. Those procedures there [in Congress] were conducted only as a formality" (Bergamo 2016).

10 The Constitution lists as crimes of responsibility the acts of the President of the Republic that attack the Constitution itself; the existence of the Union; the free exercise of the other powers; the exercise of political, individual and social rights; the internal security of the country; the administrative probity; the budget law; and the compliance with the law and judicial decisions.

11 Tomé de Souza was the first Governor General named by the Portuguese crown to control Brazil. 
In any case, the most important consideration was not that the technical arguments in favor of impeachment were or not sufficiently convincing. What mattered was that a large majority in Congress, in society, in the media, and in the financial/business world had arrived at the conclusion that it was necessary to remove the president. The fragility of the formal accusation - "a technical infraction of the Fiscal Responsibility Law" (Hagopian 2016: 120) - reminds us of something that Mahoney and Thelen (2010) highlight in the processes of institutional change: rules, as detailed as they may be, always contain an element of ambiguity, to the delight of both would-be reformers and those who are plotting to interrupt political tenures. In other words, the pedaladas fiscais were defined as a crime of responsibility primarily because a large majority of Congress so desired.

\section{THE NEW GOVERNMENT: UNPOPULAR, CONSERVATIVE, BUT WITH A BASE IN CONGRESS}

Temer assumed the presidency temporarily on 12 May, after the Chamber of Deputies had opened impeachment proceedings, and he did so definitively on 31 August, after the Senate completed the trial. The establishment of the new government, comprised of the center-right parties of Rousseff's government plus the former opposition, illustrated the priority conferred on its broad legislative base. Taking office in a delicate position, Temer initially had to accept the appointment of a deputy belonging to PSC, a small party that had formed the support base of Eduardo Cunha (the so-called centrão), as its leader in the House. By July, Temer's situation had improved and he was able to form a more reliable alliance: Rodrigo Maia (DEM) was elected, in the second round, as the substitute president of the Chamber, defeating the centrão candidate. From that point, the convergence of preferences and agendas, combined with the greater ability of the new government to deal with members of Congress, made it possible for the Legislature to act in alignment with the Executive. This is evidenced by the series of legislative victories that it achieved until December 2016, as will be clear below. ${ }^{12}$

The new government reduced the number of ministries from 32 to 25 and formed a team with a conservative profile that was most noteworthy for the complete absence of women. The PMDB, with seven cabinet portfolios, and the PSDB, with three, came to control the greatest number of ministries. ${ }^{13}$ Another

12 In early 2017, the government won the elections for the Presidencies of the Chamber and the Senate. In the Chamber, Rodrigo Maia was elected in the first round with 293 votes. The candidate of the centrão obtained 105 votes. Another 101 votes were distributed among four candidates. Four deputies spoiled their votes and ten did not vote. In the Senate, Eunício de Oliveira (PMDB) won with $75 \%$ of the votes. The results represented a expressive defeat of the centrão and showed the fragility of the legislative opposition to Temer, which remains concentrated in the PT, PDT, PC of the B and PSOL

13 The ministries of the PMDB were: Planning, Government Affairs, Agrarian Development, Secretary of Government, National Integration, Sports and Tourism. The PSDB controlled the portfolios of Justice, Cities and Foreign Affairs.. 
nine parties occupied the other posts - the PP (2), PSD, PPS, DEM, PRB, PV, PSB, PTB and PR (one each). Five ministries were delivered to ministers with no party affiliation, the Minister of the Treasury being the most important among them. The initial composition soon suffered setbacks. Under pressure, Temer had to retreat from the decision to get rid of the Ministry of Culture. Six ministers would leave their posts by the end of the year: two due to internal disagreements, three (all from the PMDB) due to involvement in the scandals, and one for having criticized Operation Car Wash. With the resulting changes, the PSDB and PPS each gained another ministry, and the PMDB decreased its share in the government. ${ }^{14}$

Between May and December, the government achieved a series of significant victories in Congress. While still serving as acting president, Temer managed to get Congress to approve a reduction in the previously fiscal goal, authorizing the government to end 2016 with a record deficit of R $\$ 170.5$ billions (Calgaro 2016). The same measure had also been taken by Rousseff to make it possible to meet the fiscal goal in 2015, but it was approved amid fierce debate, unlike in 2016. Since then, the most important measures approved have been: the extension of the DRU [Unbundling of Federal Revenue] until 2023; a high school reform (in the Chamber of Deputies); and the PEC [Constitutional Amendment Proposal] number 55 .

The DRU is a legal instrument that authorizes the Federal government to spend $30 \%$ of its revenues as it sees fit. It was created in 1994 by Fernando Henrique Cardoso and has been extended continuously since then. The last extension, in 2011, guaranteed its validity until December 2015. Rousseff had requested the extension in February 2015, but the approval was stalled in Congress. Temer managed to get approval in August 2016. The high school reform used the decree power (the so-called Medida Provisória). This method, in addition to some of the proposed changes, generated fierce debate among specialists, led to the occupation of public schools in various states, and caused the Attorney General of the Republic to send the Supreme Federal Court an opinion advocating for the unconstitutionality of the measure on the grounds that the speed of the proceedings had not been adequate to reform public policies (Oliveira 2016). Finally, the PEC 55 was approved in the Senate in December with a wide majority (65\% of the votes), thereby establishing a period of twenty years (with evaluation after ten) in which federal public expenditures may not exceed the previous year's inflation rate (Senado Noticias 2016). The measure was much

14 Fabio Medina (no party affiliation), of the Federal Attorney's Office, clashed with then Minister of Government Affairs, Eliseu Padilha (PMDB). Marcelo Callero (no party affiliation), Ministry of Culture, resigned, denouncing pressure from the Secretary of Government, Geddel Vieira Lima (PMDB). From the ministers from the PMDB, Romero Jucá (Planning) had to leave after the disclosure of statements in which he argued that after the impeachment proceeding it would be necessary to stop the bleeding - referring to the scope of Operation Car Wash. Henrique Eduardo Alves had his name mentioned in the plea bargain process. Geddel Vieira Lima left after Marcelo Callero revealed pressure to issue a construction permit in Salvador (Bahia), where the former minister had an apartment. Finally, Fabiano Silveira (no party affiliation, Oversight, Transparency and Control) was dismissed for criticizing how Operation Car Wash was conducted. 
tougher than Rousseff's 2015 proposal and sought a much longer term than any previous extension. Thus, it was strongly criticized for putting public policies in the area of health and education in at risk, and jeopardizing the adequate maintenance of the instruments of social inclusion created during the PT era.

In addition to the PEC's effects on public expenses, the new government presented a proposal to reform social security, which was again far beyond what had been announced by the previous government. To be voted on in 2017, this proposal represents the toughest legislative test for the government. The proposal sent to Congress sets the minimum retirement age at 65 , with no distinction between men and women, and raises the minimum contribution time from 15 years to 25 years. It also stipulates that full retirement would only be granted after 49 years of contributions, raises the contribution rate of federal public employees from $11 \%$ to $14 \%$, unties the Social Security floor of the minimum salary ${ }^{15}$, and raises the age at which the elderly or people with disabilities who have never contributed have a right to a pension from 65 to 70. The Military Police, firemen, and members of the Armed Forces would be excluded from the reform (Alegretti et al. 2016). ${ }^{16}$

Taken together, PEC 55, the social security reform, and the relaxation of labor laws - approved in the Chamber in April 2017 - left no doubt that for the new government, the bill for the fiscal adjustment would fall disproportionately on the shoulders of those who, in a country marked by profound social and economic inequality, depend on the State and its network of social protection and legal guarantees for work. After years of moving to the left, Brazil is taking a turn to the right.

The re-composition of the governing coalition and its victories in Congress were not enough to rid the government of the broader crisis of legitimacy. Since the beginning of the Car Wash scandal, the extensive involvement of the PMDB - a party chaired by Michel Temer for 15 years - has become clear. The situation worsened when, in November 2016, 77 Odebrecht executives started proceedings to sign plea bargains with the Federal Public Prosecutor's Office. The news threw a veil of uncertainty over the government, in addition to haunting a huge number of politicians from more than a dozen parties. In testimony leaked by the press, the company's former Vice President of Institutional Relations not only incriminated key members from government and the PMDB - Eliseu Padilha (Minister of Government Affairs), Geddel Vieira Lima (then Secretary of Government), Moreira Franco (Secretary of Partnership and Investments), and Senator Romero Jucá - but also highlighted the direct

15 In Brazil, the benefits paid by the retirement system are based on the minimum wage, which means that an increase on the second has a strong impact on the former.

16 The proposal soon faced strong opposition from society. In the early months of 2017, aware of the impossibility of cohesion of its base around the initial proposal, the government had already retreated from some of the key points, but obstacles to the approval have not been totally removed. 
involvement of President Temer in raising funds for the 2014 campaign (Casado et al. 2016). ${ }^{17}$

Together, the unpopular content of the reforms (both passed and proposed) and the unfolding of the Car Wash operation sank the Temer government's approval ratings to levels similar to Rousseff's administration. In November, a survey commissioned by the National Confederation of Industries and done by the Brazilian Public Opinion and Statistic Institute (IBOPE) showed that only 13\% of the population considered government excellent or good, while $46 \%$ rated it as bad or terrible (Amorim 2016). In July 2017, the percentage of bad/terrible would reach $70 \%$.

\section{THE MUNICIPAL ELECTIONS}

In the midst of the political crisis, Brazil went to the polls to elect its new mayors and local council members in October 2016. These mayoral elections reveal much about the state of Brazilian politics. Elections occur simultaneously in the 5,570 municipalities, making it possible for these to be interpreted as akin to midterm elections in other states (Lavareda and Telles 2015) in the sense that they serve as a thermometer for the government in command. Local electoral results in Brazil are not particularly related to the presidential election that happens two years later, but they are crucial for understanding how the composition of the Chamber of Deputies and the Legislative Assemblies will likely shift.

It is due to their importance for subsequent national and state legislative elections that we turn our attention to analyzing the results of the mayoral elections in 2016. With a new government and with a high degree of negative exposure of the political class, and the PT in particular, the 2016 municipal elections happened in an atypical climate. The campaigns were cold, with little popular engagement, and nearly imperceptible in the streets.

First, because the elections were dominated by the national agenda, especially in the large urban centers, there was a lot more news about the economic and political crisis than exposure of the candidates. The country also hosted the Olympics in the city of Rio de Janeiro in August. Voter mobilization and interest in the elections was thus well below what it is normal in the country. In São Paulo, for example, $50 \%$ of the electorate had little or no interest in the municipal election a little over a month before the day of the voting, according to research by IBOPE (Veja 2016). Similar disinterest in the municipal elections was observed in Recife (Santos 2016), Campo Grande (Globo 2016) and in Curitiba (Frey 2016), to cite only a few examples.

17 In 2017, former ministers Henrique Eduardo Alves and Geddel Vieira Lima were arrested. President Temer and the ministers Eliseu Padilha and Moreira Franco began to be investigated as part of the Car Wash scandal. 
This disinterest was also evident at the polls, as the number of people who did not vote in the first round of elections grew significantly. In 2012, 27\% of the registered Brazilian electorate did not show up to the polls, despite the fact that voting is compulsory. This number rose to 33\% in 2016. About 7 million voters did not show up to vote in the cities where there was a second round of elections. While voter abstention data may be influenced by the failure to update electoral registrations, the number of blank and spoiled ballots also increased. Comparing the second rounds of elections in 2012 and 2016, blank or null votes rose from $9 \%$ to $14 \%$.

Second, the electoral reform of 2015 shortened the duration of campaigns. According to the new law, the time candidates had to campaign decreased from 90 to 45 days, and the electoral radio and TV advertising period decreased from 45 to 35 days. In addition, campaigns stopped counting on financing from companies. This type of financing, permitted in Brazil since the 1990s, was reaffirmed in the abovementioned reform after a polemic vote in the Chamber of Deputies. ${ }^{18}$ However, the Supreme Federal Court opted to declare it unconstitutional, leading Dilma Rousseff to veto this provision. The result was almost immediate: in 2016, the campaigns had spent only a third of the amount committed in 2012.

Table 2. Result of the municipal elections 2016

\begin{tabular}{cccc}
\hline Party label & Ranking & Mayors & Population $(\%)$ \\
\hline PMDB & 1 & 1,038 & 14.2 \\
PSDB & 2 & 805 & 23.9 \\
PSD & 3 & 540 & 6.5 \\
PP & 4 & 492 & 4.8 \\
PSB & 5 & 415 & 7.9 \\
PDT & 6 & 335 & 5.8 \\
PR & 7 & 299 & 3.5 \\
DEM & 8 & 266 & 5.1 \\
PTB & 9 & 261 & 3.4 \\
PT & 10 & 254 & 2.9 \\
\hline
\end{tabular}

Source: TSE (2017).

The result of shorter, less expensive campaigns that were 'contaminated' by the national setting, may be summarized as follows: (1) PT was the party that lost

18 In a first vote, the Chamber of Deputies had rejected the proposal to retain financing by companies, but Eduardo Cunha raised the issue the following day. House rules prohibit defeated proposals from being presented again in the same legislature, however, as a workaround for this problem, Cunha introduced the matter as an amendment to another bill. 
the most territory on the country's electoral map; (2), the incumbency advantage was higher than usual; and (3) the three main state capitals each elected a mayor with a background outside of politics.

Figure 1. City governments administered by the six Brazilian majority parties (2000 to 2016)

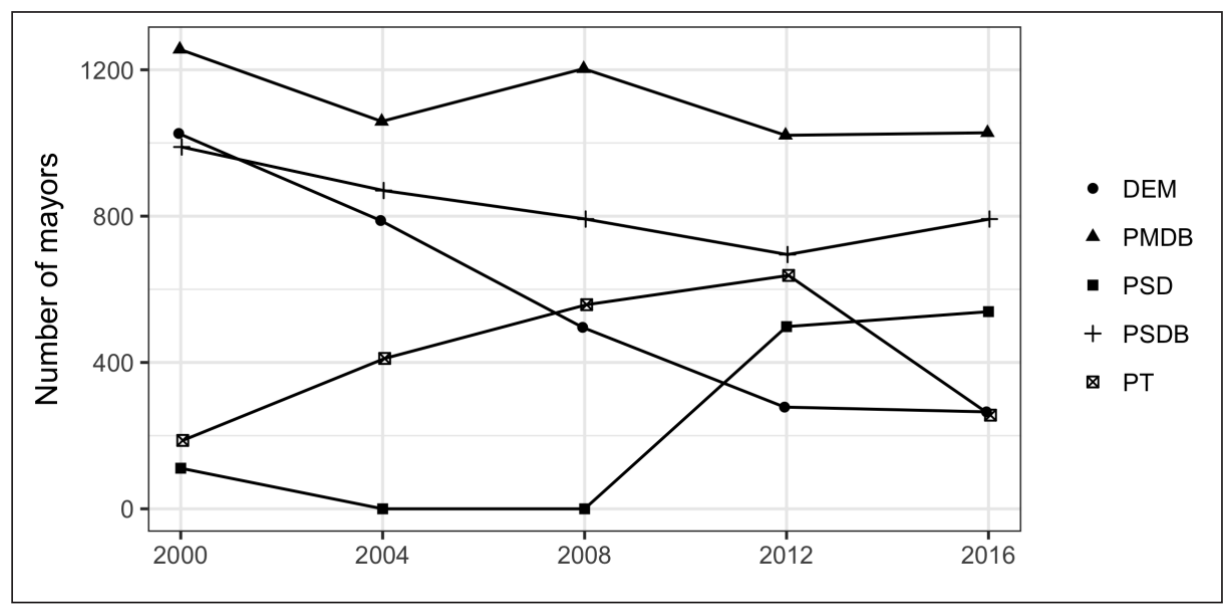

Source: TSE (2017).

While the PMDB continued to dominate the mayoral elections (wining in 1,021 cities in 2012 and 1,038 in 2016), reaffirming its status as a major party from Brazil's interior, the PT disappeared from the capitals and suffered a significant reduction in the number of cities it controlled. In 2012, at the height of its popularity as a consequence of the success of the Lula/Rousseff governments, the PT came to control more than 600 cities in the country, including São Paulo. This gave it the position of the third largest party in terms of municipal significance. In 2016, the PT only managed to elect 254 mayors, falling to the tenth largest party in terms of the number of mayoralties, behind the PSD (540 mayors), PR (299 mayors) and DEM (266 mayors).

While the PSDB came to govern the greatest number of Brazilians (24\% of the population), as well as the most large cities and the greatest percentage of municipal GDP (R $\$ 158$ billion ), the PT was transformed into an isolated party. It was the party that contested the most mayorships without making electoral coalitions. Whereas PT ran the mayoralty alone in 223 municipalities, the PMDB did so in just 150 municipalities, and the PSDB in only 75. Among the larger parties, the PT also participated in the fewest electoral coalitions for mayor. The average number of parties in coalition with PT candidates was 4.0; in the case of the PMDB, this number was 4.8 , and in the case of PSDB it was 5.3. 
The 2016 election was also noteworthy for the election of candidates with greatest name recall among the population. With the disinterest of the electorate, the reduction in the campaign period, including on the radio and on TV, and the limitations on expenses, candidates already familiar to the population tended to fare best. This new election format made change of electoral preference throughout the campaign very difficult. Moreover, what further enhanced the performance of the well-known candidates was the anti-political sentiment that dominated the municipal election. The strain on the political class due to the national context created a barrier for the population with respect to the communication used in the campaigns. In the sixteen cities researched by DataFolha between the first and second rounds, the candidate in the lead at the beginning of the election was elected mayor in all but three cities.

This feeling of being tired of the old campaign models, the promises, and the traditional arguments opened a space for the election of names fully outside of politics. In São Paulo, João Dória, a businessman in communications who contested the election without the help of political godfathers, won. His main campaign argument was that of rejecting traditional models of campaigning and governing. Although he was supported by the state's governor, Geraldo Alckmin (PSDB ), Dória's campaign did not depend on that tie. In Rio de Janeiro, a bishop of the Evangelical church, Marcelo Crivella, won. While he had been a Senator for Rio state, Crivella presented himself as an innovator and distanced himself from traditional political figures in the city. His victory represented the defeat of the PMDB, which had dominated the state since 2006. In Belo Horizonte, the non-political argument also prevailed with the victory of the former president of a soccer club, Alexandre Kalil. His campaign slogan "Enough politicians, it's Kalil's turn" did a good job capturing the sentiment of the electorate. In this case, the main parties defeated were the PSDB, in the second round, and the PT, which did not get past the first round.

All three campaigns were similar in that that none of the candidates was tied to a traditional political group in their respective cities. Although each was already participating in politics in some way, whether by financing, supporting, or even having run for other offices, neither Doria, nor Crivella, nor Kalil possessed a trajectory capable of functioning as a rejection of their names. On the other hand, they were sufficiently well-known to be familiar names even before the start of the electoral campaign.

Finally, it is also worth highlighting the growth in the number of mayoralties won by smaller parties, some of which did not exist during the 2012 elections (SD and PROS). Once the polls had closed in 2016, these groups had control of 338 municipalities, compared to 200 in the previous election.

Within this framework it is possible to speculate about the impact of the 2016 municipal elections on the general races in 2018. Given these results, it seems likely that the PT will lose power while the PSDB will make some gains. Keeping the current rules in place, we may also expect to see a growth in 
legislative fragmentation. Given the increase in the number of parties winning in the municipal elections, the same trend is likely to be evident in elections to the Chamber of. This happens because the vote for federal deputies is closely tied to the degree of support they receive from local mayors. The implication is obvious. For the coalition government to work well, the president needs to get along with party leaders with enough networks to deliver the votes of a disciplined coalition. Greater fragmentation in Congress will become more costly than the establishment of a stable and faithful coalition capable of giving support, whether pragmatic or programmatic, to the majority agenda at the polls.

\section{THE CRISIS AND DEMOCRACY IN BRAZIL}

The period between 1994 and 2014 provided strong evidence cited by those who argued that the Brazilian political system was functional and stable. The current crisis allows us to reopen this discussion briefly. After all, what has changed? In order to answer this question, it is necessary to examine two points: the relation between the executive and the legislature, and the establishment of a stable pattern of interaction among the parties in the competition for the presidency.

As shown by Figueiredo and Limongi (2008:152), presidents elected after the 1988 Constitution largely dominated the legislature's agenda, and about 75\% of their initiatives were approved. In the authors' words:

"The Brazilian political system functions adequately when other political systems of the world are taken as a parameter for this judgment. There are certainly no problems of governability, if the term is understood in its most immediate and direct meaning. The government is capable of approving laws, and there are no obstacles to its pretensions in the National Congress. There is no paralysis in decision making. Changes in public policies, seen as impossible under the prevailing institutions, many of them requiring constitutional amendments, were approved in Congress."

However, the good performance of governments never allowed Brazilian presidentialism to be considered an "imperial" regime, in which the legislature could be taken as a passive actor easily controlled by a powerful executive. Throughout this period, Congress has always been able to interfere in the game by modifying or even blocking presidential initiatives. More recently, Almeida (2014) has called attention to the emergence of a new framework in the relationship between the two powers. According to the author, a comparison between the periods 1989-2004 and 2005-2014 shows that, excluding budgetary 
laws (the exclusive domain of the executive branch in Brazil), the legislative dominance rate of the president had fallen by half, and the number of initiatives passed by urgency request - which reduces substantially the processing time in the congressional commissions system - decreased in the same proportion. We would be facing a more shared agenda among the powers, a more proactive Congress and a more decentralized legislative process, in which the commissions acquire greater relevance.

It is worth emphasizing that these changes have occurred in the absence of major constitutional reforms that would alter the rules of the game. Using the typology introduced by Mahoney and Thelen (2010), it can be said that the Brazilian Congress went through a gradual process of institutional change in which the rules remained the same but their impact were altered due to changes in the environment.

These environmental changes may be characterized as follows. Today, the country has a generation of politicians whose ties to the constituents of 1988 are increasingly rare. In turn, this generation is subjected to intense pressure from public opinion, which sees Congress and legislative activity as something deserving of little trust. In this context, there is a prevailing sentiment, especially among deputies, that it is necessary not only to expand the powers of the legislative branch, but also to overcome the limitations imposed on the agenda power of the deputies taken individually ${ }^{19}$. Surveys done by the Legislative Studies Center of the Federal University of Minas Gerais Department of Political Science in the 2007/2011 and 2011/2015 legislatures show that $68 \%$ of deputies consider it necessary to increase the legislature's power at the expense of the executive branch, while only $1.6 \%$ point to the deputies as actors capable of interfering in the house's agenda.

At the same time, the effective number of parties in the Chamber of Deputies increased from 7.1 in 1998 to 13.3 in 2014. It is not possible, within the scope of this article, to discuss all the implications of this trend. However, when the number of small and medium parties grows while the larger parties lose strength, the relative power of the leaders decreases as the difficulty of coordination between then increases.

Beyond what was mentioned above, these elements help to complete the framework in which Cunha ascended to the Presidency of the Chamber and understand the prestige he acquired. After forming a party coalition more powerful than any other party and electing a Board of Directors formed by deputies of the so-called "lower clergy", the former MP was praised for the pace of legislative work and strong leadership during his presidency.

19 The House of Representatives' Internal Rules concentrate power resources in the hands of party leaders and limit the action of each deputy. 
It was in this context that Rousseff's mistakes in leading her coalition had disastrous consequences. If the impeachment itself is not sufficient to give reason to those who see Brazilian coalition presidentialism as a regime vulnerable to crises of decision-making, it does underline the importance of being able to establish and maintain a coalition of support in Congress. Overall, there were no relevant changes in the government coalition, with the maintenance of a similar distribution of power between government and opposition within the Legislature since Lula's government (Amorim Neto and Coelho 2008; Anastasia and Melo 2009; Renno 2010; Melo and Santos 2013). But the changes in the dynamics of the Congress, mentioned above, added to the party system fragmentation and the corruption crisis installed after 2014 demanded greater capacity for negotiation on the part of the President. And the ex-president, as Ribeiro, Visoná and Cassota (2015) remember, arrived at the Palácio do Planalto without ever having held an elective office and without previous experience of negotiation and political articulation. It is not surprising, therefore, that Rousseff had already presented problems with her coalition in the House since the second year of her first term (Melo and Santos 2013). After re-election, these mistakes - already evident in the appointment of the first Ministry - proved to be fatal, and the government ended up unable to conduct its agenda.

The preceding twenty years of stability are also related to the fact that the competition for the presidency was controlled by the parties and acquired a definite pattern, revolving around two programmatically distinct coalitions that converged at the center of the ideological spectrum - one commanded by the PT and another by the PSDB. The introduction of a bipartisan dynamic, within a highly fragmented system, defined the main actors, their strategies and proposals. In sum, it gave predictability to electoral competition. The tendency towards moderation, in turn, defined reasonable limits to the political game and allowed it to maintain important elements of continuity in the elaboration of public policies (Melo and Câmara 2012).

At this point, the Car Wash episode reveals its double face. On one side, it shows that the mechanisms of control over political actors - in the executive and the legislative branches - have been functioning satisfactorily. The autonomous actions of the Public Prosecutor's Office and the Federal Police, as well as the positions taken by the Supreme Federal Court, provide indisputable evidence that Brazil cannot be considered a "delegative" democracy.

But the investigations also exposed the entrails of the political system by revealing the dominant pattern in relationships between businessmen, politicians and parties in the country. As argued by Hagopian (2016: 120) "stronger horizontal accountability institutions [...] have paradoxically eroded the bonds of vertical accountability [and] generated demands for political representation that the existing party system has not been able to meet." It is noteworthy that surveys from DataFolha show that the percentage of voters who support any party has reached its lowest level since 1989. The impact of these corruption revelations on an electorate that has always distrusted politicians, parties and politics has 
shown itself to be significant, opening space for the criminalization of politics and the emergence and success of candidates who affirm that they are not politicians, and even, though to a lesser degree, for explicit manifestations of support for a return to military dictatorship.

The strong erosion of ties between politicians, parties and citizens is the farreaching aspect of the crisis and will not be mitigated by the re-composition of the executive-legislative relationship reached by the new government. Its most immediate link is with electoral funding, but its confrontation will depend on reforms in the electoral system that cannot be addressed within the limits of this article.

It is likely that the PT crisis and the stress to which other parties are subjected will open a new period in the electoral and party competition in the country. For the first time, since the election of Fernando Collor in 1989, there is real space for the emergence of outsiders. It is not possible to predict what will happen to the PT, but if s the party repeats the bad performance of 2016 in the 2018 election, the impact on the party system will be significant. Since redemocratization, the existence of an electorally competitive leftist party with social roots has been decisive in providing an institutional expression for a wide range of popular demands. While it did well in the municipal elections, the PSDB is still not capable of holding the system. It should be noted that PT's retreat also showed the forces on the right that it is no longer necessary to shelter under the PSDB umbrella - the greatest evidence in this regard is the surge in popularity of the candidacy of Deputy Jair Bolsonaro, who, among other things, is known for dedicating his vote in the impeachment process to the memory of one of the most notorious torturers of the dictatorial period. Finally, three potential party candidates for the next presidential election - José Serra, Geraldo Alckmin and Aécio Neves - are all involved in Operation Car Wash. ${ }^{20}$

PT relies on Lula's return in 2018 to remain competitive. Although the former president maintains an electoral base capable of making him the front-runner in the polls, the strategy is risky: Lula is being investigated in court proceedings that, depending on the outcome, could make his candidacy inviable ${ }^{21}$.

Democracy is not at risk in Brazil. But the country is experiencing a political crisis for which there seems to be no simple cure. Politicians and parties are being strongly questioned in their legitimacy. As a direct consequence of this scenario, the presidential election of 2018 is surrounded by a thick veil of uncertainty. Moreover, everything suggests that the Brazilian party system is on the brink of a change that will affect, in the words of Mair (2006), the core of

20 José Serra was accused of receiving, in Switzerland, US\$ 23 million from Odebrecht (Folha de São Paulo, October 28, 2016). The governor of São Paulo, Geraldo Alckmin, appears in the payment spreadsheets of the same company under the code name "Santo" (FSP, November 26). Aécio Neves is being investigated in several cases since 2016 and in 2017 had his term in the Senate temporarily suspended by judicial decision.

21 In 2017 Lula was convicted in one of these cases. If the sentence is settled in a second instance, the former president becomes ineligible. 
any system: the structure of the competition for the central government. What is worrisome is that there is no guarantee that another pattern may emerge, which allows us to assume a period of instability ahead.

\section{REFERENCES}

Alegretti, Laís. 2016, 12 December. "Reforma da Previdência chega ao Congresso nesta terça, anuncia Temer." Folha de São Paulo. Retrieved from http:/ / www1.folha.uol.com.br/ mercado/2016/12/1838637-reforma-da-previdencia-chega-ao-congresso-nesta-terca-anuncia-temer.shtm

Almeida, Acir. 2014. "A produção legislativa no pós-1988: tendências recentes e desafios." In Brasil em desenvolvimento: estado, planejamento e políticas públicas, edited by Leonardo Monasterio, Marcelo Neri and Sergei Soares. Brasília: Ipea, vol. 2, 247-260

Amaral, Oswaldo and Pedro Floriano Ribeiro. 2015. “Por que Dilma de novo? Uma análise exploratória do Estudo Eleitoral Brasileiro de 2014." Revista de Sociologia e Política 23(56): 107-123.

Ames, Barry. 2001. The Deadlock of Democracy in Brazil. Ann Arbor: Michigan University Press.

Amorim, Felipe. 2016, 12 December. "Reprovação a governo Temer cresce e vai a 46\%, diz pesquisa." UOL. Retrieved from https://noticias.uol.com.br/politica/ultimas-noticias /2016/12/16/cni-governo-temer.htm?cmpid=copiaecola

Amorin Neto, Octávio and Carlos Frederico Cohelo. 2008. “Brasil en el 2007: el desencuentro entre la economia y la politica." Revista de Ciencia Política 28(1): 81-102.

Anastasia, Fátima and Carlos Ranulfo Melo. 2009. "Brasil: dos décadas de democracia." Revista de Ciencia Política 29(2): 275-300.

Araújo, Marina and Walace Lara. 2016, 29 December. “2016 vai encerrar com 12 milhões de desempregados, de acordo com IBGE." Jornal Da Globo. Retrieved from http://g1.globo.com/jornal-da-globo/noticia/2016/12/2016-vai-encerrar-com-12-milhoes-de-desempregados-de-acordo-com-ibge.html

Bächtold,Felipe.2016,13March. "Protestocresce, masmanifestantemantémperfildealta renda." Folha. Retrieved from http://www1.folha.uol.com.br/poder/2016/03/1749640-protesto-cresce-mas-manifestante-mantem-perfil-de-alta-renda.shtml

Bergamo, Monica. 2016, 1 December. "Para Joaquim Barbosa, governo Temer corre o risco de não chegar ao fim." Folha. Retrieved from http://www1.folha.uol.com.br/ poder /2016/12/1837292-governo-temer-corre-o-risco-de-nao-chegar-ao-fim.shtml

Borgan, Thomas C. 1999. Horses in Midstream: US Midterm Elections and Their Consequences, 1894-1998. Pittsburgh: University of Pittsburgh Press.

Boulos, Guilherme. 2015, 19 February. "A cara de pau de Eduardo Cunha." Folha. Retrieved from http://www1.folha.uol.com.br/colunas/guilhermeboulos/2015/02/1591244a-cara-de-pau-de-eduardo-cunha.shtml

Brito, Ricardo. 2015, 5 January. "Renan avisa a ministros de Dilma que PMDB pode ficar independente no Senado." Retrieved from http://politica.estadao.com.br/noticias/ geral,renan-avisa-a-ministros-de-dilma-que-pmdb-pode-ficar-independente-no-senado, 1615584

Calgaro, Fernanda. 2016, 25 May. “Congresso reduz meta fiscal e autoriza déficit de até R\$ 170,5 bilhões." G1 Globo. Retrieved from http://g1.globo.com/economia/noticia/2016/05/congresso-reduz-meta-fiscal-e-autoriza-deficit-de-ate-r-1705-bilhoes. html

Campos, Eduardo and Cristiane Bonfanti. 2017, 31 January. “Deficit primario do setor publico atinge 2,47\% do PIB em 2016." Valor. Retrieved from http://www.valor.com.br/brasil/4853506/deficit-primario-do-setor-publico-atinge-247-do-pib-em-2016

Casado, Leticia et al. 2016, 10 December. "Nome de Temer é citado 43 vezes em delação de executivo da Odebrecht." Folha. Retrieved from http://www1.folha.uol.com.br/ 
poder /2016/12/1840250-nome-de-temer-e-citado-43-vezes-em-delacao-de-executivo-da-odebrecht.shtml

Datafolha. 2016. "Opiniao Publica." Retrieved from http://datafolha.folha.uol.com.br/opiniaopublica/

Figueiredo, Argelina and Fernando Limongi. 2008. "Instituciones políticas y governabilidad: desempeño del gobierno y apoyo legislativo en la democracia brasileña." In La democracia brasileña - balance y perspectivas para el siglo XXI, edited by Manuel Alcántara Saez and Carlos Ranulfo Melo. Salamanca: Ediciones Universidad de Salamanca, 117-156.

Frey, João Guilherme. 2016, 26 August. "A pouco mais de um mês para as urnas, curitibanos não mostram interesse na eleição." Gazeta do Povo. Retrieved from http://www. gazetadopovo.com.br/vida-publica/eleicoes/2016/a-pouco-mais-de-um-mes-para-as-urnas-curitibanos-nao-mostram-interesse-na-eleicao-e3s610m6vz3qnmu82rcyhid5k

Gaspari, Elio. 2016. "Há golpe." Folha. Retrieved from http:/ /www1.folha.uol.com.br/colunas/eliogaspari/2016/06/1786670-ha-golpe.shtml

Globo. 2016. "Ibope mostra intenção de voto, votos válidos e interesse pela eleição em Campo Grande." Retrieved from http://g1.globo.com/politica/eleicoes/2016/videos/t/todos-os-videos/v/ibope-mostra-intencao-de-voto-votos-validos-e-interesse-pela-eleicao-em-campo-grande/5346625/

Hagopian, Frances. 2016. "Brazil's Accountability Paradox." Journal of Democracy 27(3): 119128.

Hochstetler, Kathryn. 2007. "Repensando o presidencialismo: contestações e quedas de presidentes na América do Sul." Lua Nova 72: 9-46.

Lavareda, Antonio and Telles Helcimara. 2015. Como o eleitor escolhe seu prefeito: campanha e voto nas eleições municipais. Rio de Janeiro: Editora FGV.

Limongi, Fernando. 2015. "O passaporte de Cunha e o impeachment - a crônica de uma tragédia anunciada." Novos Estudos 103: 99-112

Mahoney, James and Kathelen Thelen. 2010. Explaining Institutional Change: Ambiguity, Agency and Power. New York: Cambridge University Press.

Mainwaring, Scott. 1999. Rethinking Party Systems in the Third Wave of Democratization: The Case of Brazil. Stanford: Stanford University Press.

Mair, Peter. 2006. "Party System Change". In Handbook of Party Politics, edited by Richard Katz and William Crotty. London, Sage Publications; 63-73

Marchesini, Lucas. 2016, 21 November. "Fazenda piora projeção para o PIB de 2016 e de 2017." Valor. Retrieved from http:/ / www.valor.com.br/brasil/4782833/fazenda-piora-projecao-para-o-pib-de-2016-e-de-2017

Marsteintredet, Leiv. 2008. "Las consecuencias sobre el régimen de las interrupciones presidenciales en América Latina." América Latina Hoy 49: 31-50.

Matais, Andreza, Vera Rosa and Beatriz Bulla. 2014, 30 October. "PSDB de Aécio Neves pede auditoria na votação." Estadão. Retrieved from http:/ / politica.estadao.com.br/noticias/geral,psdb-de-aecio-neves-pede-auditoria-na-votacao,1585755

Melo, Carlos Ranulfo and Rafael Câmara. 2012. "Estrutura da competição pela Presidência e sistema partidário no Brasil." Dados 55(1): 71-117.

Melo, Carlos Ranulfo and Santos, Manoel Leonardo. 2013. "Y la nave va: Brasil bajo Dilma Rousseff". Revista de Ciencia Política, 33, 1, 55-81.

Melo, Carlos Ranulfo. 2015. "The 2014 Elections and the Brazilian Party System." Brazilian Political Science Review 9(1): 93-114.

Negretto, Gabriel. 2006. "Minority Presidents and Democratic Performance in Latin America." Latin American Politics and Society 48(3): 67-74.

Oliveira, Mariana. 2016, 12 December. "MP da reforma do ensino médio é inconstitucional, diz Janot ao STF." TV Globo. Retrieved from http://g1.globo.com/educacao/noticia/ janot-diz-que-mp-do-ensino-medio-viola-constituicao.ghtml

Pérez-Liñán, Aníbal. 2007. Presidential Impeachment and the New Political Instability in Latin America. New York: Cambridge University Press. 
Pérez-Liñán, Aníbal. 2008. "Instituciones, coaliciones callejeras e inestabilidad política: perspectivas teóricas sobre las crisis presidenciales." América Latina Hoy 49:105-126.

Renno, Lucio. 2010. "Executive-Legislative Relations in Brazil: Is 2009 the First Year of the Rest of Our Lives?" Revista de Ciencia Política 30(2): 213-230.

Ribeiro, Pedro Floriano, Amanda Visoná, and Priscilla Leine Cassota. 2016. "Brasil: un país en compás de espera." Revista de Ciencia Política 36(1):51-74.

Santos, Giselly. 2016, 1 October. "Mais da metade dos recifenses não têm interesse na eleição." LeiaJa. Retrieved from http://www.leiaja.com/politica/2016/10/01/mais-da-metade-dos-recifenses-nao-tem-interesse-na-eleicao/

Senado Noticias. 2016, 13 December. "PEC que restringe gastos públicos é aprovada e vai a promulgação." Retrieved from http://www12.senado.leg.br/noticias/materias/2016/12/13/pec-que-restringe-gastos-publicos-e-aprovada-e-vai-a-promulgacao

UOL. 2015, 12 December. "Protestos pelo impeachment têm adesão menor; organizadores chamam de 'esquenta.'" Retrieved from https://noticias.uol.com.br/politica/ultimas-noticias /2015/12/13/manifestacoes-pro-impeachment-tem-baixa-adesao-pelo-brasil.htm

UOL. 2016, 13 March. “Brasil tem maior manifestação contra Dilma." Retrieved from https:/ / noticias.uol.com.br/politica/ultimas-noticias/2016/03/13/brasil-tem-maior-manifestacao-contra-dilma.htm?cmpid=copiaecola

Veja. 2016, 24 August. "Em São Paulo, eleitores ainda não mostram interesse pela eleição." Retrieved from http://veja.abril.com.br/politica/eleitores-ainda-nao-sabem-o-ndos-candidatos/

Venceslau, Pedro and Elizabeth Lopes. 2015, 19 April. "Cunha rejeita tese de impeachment de Dilma por 'pedaladas fiscais.'" Estadão. Retrieved on 1 August 2017 fromhttp:/ / politica.estadao.com.br/noticias / geral,cunha-rejeita-tese-de-impeachment-de-dilma-por-pedaladas-fiscais, 1672754

Felipe Nunes is an Asistant Professor of the Political Science Department at the Federal University of Minas Gerais (Brazil). His research focuses on comparative studies of political institutions, distributive politics of presidential systems in Latin America and research methods for social sciences. He received the Swarr Prize for the Best Political Science paper at UCLA in 2014 and the Award for the Best poster presented in the Annual Meeting of the Society for Political Methodology in 2013.

Carlos Ranulfo Melo is Professor of the Political Science Department at the Federal University of Minas Gerais (Brazil). He is author of Retirando as cadeiras do lugar: migração partidária na Câmara dos Deputados (Editora UFMG), co-author of Governabilidade e Representação Política na América do Sul (Konrad-Adenauer/UNESP) and co-editor of La democracia brasileña: balance y perspectivas para el siglo XXI (Ed. Salamanca). He works with parties and party systems, legislative studies and democratic institutions. 


\section{APPENDIX 1}

\section{LIST OF POLITICAL PARTY ACRONYMS}

DEM - Democratas [Democrats]

NOVO - Partido Novo [New Party]

PC do B - Partido Comunista do Brasil [Communist Party of Brazil]

PCB - Partido Comunista Brasileiro [Brazilian Communist Party]

PCO - Partido da Causa Operária [Workers' Cause Party]

PDS - Partido Democrático Social [Social Democratic Party]

PDT - Partido Democrático Trabalhista [Labor Democratic Party]

PEN - Partido Ecológico Nacional [National Environmental Party]

PHS - Partido Humanista da Solidariedade [Humanist Party for Solidarity]

PMB - Partido da Mulher Brasileira [Brazilian Woman's Party]

PMDB - Partido do Movimento Democrático Brasileiro [Brazilian Democratic Movement Party]

PMN - Partido da Mobilização Nacional [National Mobilization Party]

PP - Partido Progressista [Progressive Party]

PPL - Partido Pátria Livre [Free Homeland Party]

PPS - Partido Popular Socialista [Socialist People's Party]

PR - Partido da República [Party of the Republic]

PRB - Partido Republicano Brasileiro [Brazilian Republican Party]

PROS - Partido Republicano da Ordem Social [Social Order Republican Party]

PRP - Partido Republicano Progressista [Progressive Republican Party]

PRTB - Partido Renovador Trabalhista Brasileiro [Brazilian Labor Renewal Party]

PSB - Partido Socialista Brasileiro [Brazilian Socialist Party]

PSC - Partido Social Cristão [Christian Social Party]

PSD - Partido Social Democrático [Democratic Social Party] 
PSDB - Partido da Social Democracia Brasileira [Brazilian Social Democracy Party]

PSDC - Partido Social Democrata Cristão [Christian Democrat Social Party]

PSL - Partido Social Liberal [Liberal Social Party]

PSOL - Partido Socialismo e Liberdade [Socialism and Liberty Party]

PSTU - Partido Socialista dos Trabalhadores Unificado [Unified Workers' Socialist Party]

PT - Partido dos Trabalhadores [Workers' Party]

PTB - Partido Trabalhista Brasileiro [Brazilian Labor Party]

PTC - Partido Trabalhista Cristão [Christian Labor Party]

PT do B - Partido Trabalhista do Brasil [Labor Party of Brazil]

PTN - Partido Trabalhista Nacional [National Labor Party]

PV - Partido Verde [Green Party]

REDE - Rede Sustentabilidade [Sustainability Network]

SD - Solidariedade [Solidarity] 